\title{
UPAYA PENINGKATAN HASIL BELAJAR FISIKA TEKNIK DENGAN PENDEKATAN PROBLEM POSING MELALUI KEGIATAN LESSON STUDY
}

\author{
Erwin Komara Mindarta1), Eddy Sutadji²), Windra Irdianto ${ }^{3)}$, Emdi Ramadhana Putra ${ }^{4}$, \\ 1,3,4 Pendidikan Teknik Otomotif, Universitas Negeri Malang \\ 2 Pendidikan Teknik Mesin, Universitas Negeri Malang \\ Email: erwin.komara.ft@um.ac.id, eddy.sutadji.ft@um.ac.id, windra.irdianto.ft@um.ac.id, \\ emdi.ramadana.1605136@students.um.ac.id
}

\begin{abstract}
ABSTRAK
Fisika teknik mengarahkan mahasiswa memahami konsep dasar fisika teknik, gerak dan energi, tumbukan dan listrik di bidang otomotif. Salah satu pokok bahasannya adalah menghitung impuls dan momentum pada kendaraan yang mana melibatkan operasi matematika, yang dapat menimbulkan rasa cemas pada diri pebelajar. Sehingga dibutuhkan pendekatan pembelajaran yang dapat menurunkan kecemasan matematis, yaitu problem posing. Metode penelitian menggunakan pendekatan kuantitatif dengan model penelitian tindakan, yaitu menekankan pada kegiatan (tindakan) dengan mengujicobakan suatu ide ke dalam praktek atau situasi nyata dalam skala mikro yang diharapkan kegiatan tersebut mampu meningkatkan kualitas. Dalam upaya meningkatkan hasil belajar mahasiswa, idenya adalah mengujicobakan / menerapkan pendekatan problem posing melalui kegiatan (tindakan) lesson study. Penerapan problem posing bertujuan untuk meningkatkan hasil belajar mahasiswa. Sebelum diterapkan, dilakukan lesson study (plan-do-see). Sampel berjumlah 32 mahasiswa, dengan teknik pengumpulan data observasi \& pre-test \& post-test. Data dianalisis deskriptif dan tes "t". Hasil penelitian terdapat peningkatan hasil belajar dibuktikan skor post-test $=89,75$ lebih tingi dari skor pre-test $=78,5$.
\end{abstract}

Kata kunci: fisika teknik, problem posing, lesson study

\begin{abstract}
Engineering physics directs students to understand the basic concepts of engineering physics, motion and energy, collisions and electricity in the automotive field. One of the subjects is calculating impulses and momentum in vehicles which involve mathematical operations, which can cause anxiety for students. So we need a learning approach that can reduce mathematical anxiety, namely problem posing. The research method uses a quantitative approach to the action research model, which emphasizes activities (actions) by testing an idea into practice or a real situation on a micro scale that is expected to increase the quality of the activity. In an effort to improve student learning outcomes, the idea is to try / apply the problem posing approach through lesson study activities. The application of problem posing aims to improve student learning outcomes. Before being implemented, a lesson study (plan-do-see) is conducted. The sample consisted of 32 students, with observation \& pre-test \& post-test data collection techniques. Data were analyzed descriptively and the " $t$ " test. The results of the study showed an increase in learning outcomes evidenced post-test score $=89.75$ higher than the pre-test score $=78.5$.
\end{abstract}

Keywords : engineering physics, problem posing, lesson study

\section{PENDAHULUAN}

Matakuliah fisika teknik pada Program Studi S1 Pendidikan Teknik Otomotif Jurusan Teknik Mesin Fakultas Teknik Universitas Negeri Malang (Prodi S1 PTO FTUM) ditinjau dari substansi pembelajaran memiliki karakteristik yang berbeda dengan matakuliah kimia pada Fakultas MIPA. Fisika teknik pada S1 PTO FTUM mengarahkan mahasiswa memahami konsep dasar fisika teknik, gerak dan energi, tumbukan dan listrik di bidang otomotif. Soal-soal yang disajikan di diktat idealnya berbasis penerapan konsep dasar fisika teknik, gerak dan energi, tumbukan dan listrik dalam mekanika mobil sehari-hari [1]. 
Namun fakta pembelajaran menunjukkan bahwa 1) soal-soal yang disajikan di diktat bersifat dasar, 2) pembelajaran terkesan mengulangi materi yang sudah peserta didik dapatkan ketika SMA, 3) penyelesaian soal di ruang kelas tidak optimal, karena proses internalisasi setiap mahasiswa berbeda-beda sehingga memerlukan waktu yang berbeda-beda juga untuk menyelesaikan soal. Waktu belajar terbatas 2 jam studi, akan lebih baik jika mahasiswa diberikan kesempatan untuk belajar dengan difasilitasi sebuah pendekatan pembelajaran sebagai rambu-rambu dan kontrol proses belajar.

Pendekatan pembelajaran tersebut adalah problem posing. Problem berarti masalah atau soal dan posing berasal dari kata to pose yang artinya mengajukan atau membentuk [2]. Ada dua usulan lagi untuk problem posing yaitu membuat soal [3] dan pengkonstruksian masalah [4]. Strategi problem posing dapat diangkat menjadi pendekatan yang tepat untuk mengkaji pokok bahasan dalam ilmu fisika teknik yang melibatkan operasi matematika. Penelitian-penelitian tentang keefektifan strategi problem posing menunjukkan temuan bahwa strategi tersebut meningkatkan kemampuan berfikir matematis ([5]-[7]).

Untuk meningkatkan kualitas penerapan pendekatan problem posing perkuliahan fisika teknik, dilakukan lesson study. Lesson study adalah suatu pendekatan peningkatan pembelajaran yang awal mulanya dikembangkan di Jepang [8]. Stepanek menjelaskan bahwa Lesson study adalah suatu proses kolaboratif dimana sekelompok pendidik mengidentifikasi suatu masalah pembelajaran dan merancang suatu skenario pembelajaran (tahap plan), membelajarkan peserta didik sesuai skenario yang dilakukan salah seorang pendidik, sementara yang lain mengamati (tahap do), merefleksi dan mengevaluasi (tahap see), serta merevisi skenario pembelajaran.

Perry dkk [9] menjelaskan bahwa lesson study adalah salah satu model pendekatan pengembangan profesi melalui "belajar dari praktek". Selama lesson study, para pendidik merumuskan tujuan pembelajaran dan pengembangan dalam jangka panjang; secara kolaboratif bekerja pada "penelitian pembelajaran" untuk mencapai tujuan pembelajaran; mengamati, mendokumentasikan dan mendiskusikan respon peserta didik terhadap pembelajaran; dan meninjau kembali pembelajaran tersebut, serta memperluas pendekatan pembelajaran.

Pada penelitian ini kegiatan lesson study akan dilakukan pada matakuliah fisika teknik pada pokok bahasan menghitung impuls dan momentum pada kendaraan, karena materi ini pada matakuliah fisika teknik secara umum merupakan materi yang cukup rumit. Tujuan yang ingin dicapai adalah terjadinya peningkatan hasil belajar mahasiswa pada matakuliah fisika teknik pokok bahasan menghitung impuls dan momentum pada kendaraan dengan pendekatan problem posing melalui kegiatan lesson study.

Beberapa hasil penelitian yang mendukung pada penelitian ini di antaranya adalah penelitian White \& Lim [10] menunjukkan bahwa lesson study merupakan sebuah kegiatan di mana pendidik dapat mengembangkan proses pengembangan pembelajaran dan keterampilan profesional dalam meningkatkan hasil pembelajaran peserta didik. TMS Haratua, dkk. [11] menyimpulkan bahwa implementasi lesson study dapat meningkatkan kualitas hasil perkuliahan. Manfaat dari penelitian ini adalah mahasiswa dapat meningkat hasil belajarnya melalui pembelajaran fisika teknik dengan pendekatan problem posing, dapat belajar dalam suasana yang menyenangkan dan interaktif, serta menumbuhkan sikap mandiri.

\section{METODE}

Metode penelitian menggunakan pendekatan kuantitatif dengan model penelitian tindakan. Zuriah [12] mengemukakan bahwa penelitian tindakan menekankan pada kegiatan (tindakan) dengan mengujicobakan suatu ide ke dalam praktek atau situasi nyata dalam skala mikro yang diharapkan kegiatan tersebut mampu memperbaiki, meningkatkan kualitas, dan melakukan perbaikan. Tujuan penelitian ini adalah meningkatkan hasil belajar mahasiswa. Idenya adalah mengujicobakan / menerapkan pendekatan problem posing melalui kegiatan (tindakan) lesson study.

Penerapan pendekatan problem posing pada mata kuliah fisika teknik pada pokok bahasan menghitung impuls dan momentum pada kendaraan ini dilaksanakan melalui kegiatan lesson study di FT UM. Kegiatan ini diikuti oleh dosen-dosen dari jurusan lain di FT UM. Proses kegiatan dilakukan dengan 3 tahap yaitu: tahap plan (perencanaan), tahap do (implementasi dan pengamatan), dan tahap see (refleksi dan evaluasi).

Instrumen yang digunakan adalah 1) lembar observasi pembelajaran dalam kegiatan lesson study untuk observer, dan 2) instrumen pre-test \& post-test. Populasi dari penelitian ini adalah mahasiswa semester 1 Prodi S1 PTO FTUM. Sampel dari penelitian ini diambil 1 kelas berjumlah 32 mahasiswa menggunakan teknik sampling kluster. Teknik pengumpulan data yang digunakan dalam 
penelitian ini adalah 1) observasi (pengamatan), dan 2) pre-test \& post-test. Teknik analisis data yang digunakan adalah analisis deskriptif untuk hasil observasi dan tes " $\mathrm{t}$ " untuk dua sampel kecil yang satu sama lain saling berhubungan yaitu pre-test \& post-test.

Penelitian ini dilakukan dengan mengikuti tahapan atau prosedur sebagai berikut: 1) Tahap Plan: dosen model bersama dosen-dosen dari jurusan lain di FT UM membahas satuan acara perkuliahan (SAP) sebagai skenario pembelajaran/lesson plan, 2) Tahap Do: dosen model menerapkan pendekatan problem posing pada mata kuliah fisika teknik pada pokok bahasan menghitung impuls dan momentum pada kendaraan, sementara dosen lain mengamati sebagai observer, dengan langkah-langkah skenario pembelajaran pada Tabel 1. 3) Tahap See: dosen model bersama dosen-dosen dari jurusan lain di FT UM bersama-sama merefleksi pembelajaran.

Tabel 1. Langkah-langkah Kegiatan dalam Strategi Problem Posing

\begin{tabular}{cl}
\hline No. & \multicolumn{1}{c}{ Kegiatan Pembelajaran } \\
\hline 1 & Membuka kegiatan pembelajaran. \\
2 & Mengadakan pre-test \\
3 & Menyampaikan tujuan pembelajaran. \\
4 & Menyampaikan materi pelajaran. \\
5 & Memberi contoh-contoh soal dan penyelesaiannya. \\
6 & Memberi kesempatan untuk bertanya. \\
7 & Memberi kesempatan kepada pembelajar untuk membentuk soal dari kondisi yang \\
8 & diberikan dan mempertukarkan serta mendiskusikan. \\
9 & Mempersilahkan pebelajar untuk mempresentasikan soal bentukannya. \\
& membentuk soal sebanyak-banyaknya. \\
10 & Mempersilahkan pebelajar untuk mempertukarkan soal bentukannya dengan \\
& pebelajar lain dan mendiskusikan, sementara asesmen dilakukan. \\
11 & Mengarahkan pebelajar untuk menarik kesimpulan. \\
13 & Membuat rangkuman berdasarkan kesimpulan pebelajar. \\
14 & Mengadakan post-test
\end{tabular}

Diadopsi dan diadaptasi dari Iskandar [2].

\section{HASIL DAN PEMBAHASAN}

Hasil Penelitian

Hasil Tahap Plan

Rangkuman hasil pembahasan satuan acara perkuliahan (SAP) sebagai skenario pembelajaran/lesson plan oleh dosen model bersama dosen-dosen dari jurusan lain di FT UM disajikan pada Tabel 2 berikut.

Tabel 2. Rangkuman Hasil Pembahasan SAP

\begin{tabular}{|c|c|c|}
\hline No. & Indikator & Kesimpulan \\
\hline 1 & $\begin{array}{l}\text { Penjabaran indikator pencapaian kompetensi mengacu pada } \\
\text { kompetensi dasar }\end{array}$ & Sangat Baik \\
\hline 2 & $\begin{array}{l}\text { Penjabaran tujuan pembelajaran mengacu pada indikator } \\
\text { pencapaian kompetensi }\end{array}$ & Sangat Baik \\
\hline 3 & Menggunakan kata kerja operasional yang dapat diukur/diamati & Baik \\
\hline 4 & $\begin{array}{l}\text { Ketertarikan dan keterpaduan antara kompetensi dasar, indikator } \\
\text { pencapaian dan tujuan pembelajaran }\end{array}$ & Baik \\
\hline 5 & $\begin{array}{l}\text { Kesesuaian materi pembelajaran yang disajikan dengan tujuan } \\
\text { pembelajaran }\end{array}$ & Baik \\
\hline 6 & Memperhatikan perbedaan tingkat kemampuan pebelajar & Sangat Baik \\
\hline 7 & Berorientasi pada kebutuhan belajar pebelajar & Sangat Baik \\
\hline 8 & Kesesuaian pendekatan pembelajaran dengan tujuan pembelajaran & Baik \\
\hline 9 & $\begin{array}{l}\text { Kesesuaian pendekatan pembelajaran dengan materi } \\
\text { pembelajaran }\end{array}$ & Sangat Baik \\
\hline
\end{tabular}




\begin{tabular}{|c|c|c|}
\hline No. & Indikator & Kesimpulan \\
\hline 10 & $\begin{array}{l}\text { Kesesuaian pendekatan pembelajaran dengan karakteristik } \\
\text { pebelajar }\end{array}$ & Sangat Baik \\
\hline 11 & Pemberdayaan pebelajar dalam kegiatan pembelajaran & Baik \\
\hline 12 & etepatan apersepsi dan motivasi pada kegiatan pendahuluan & Baik \\
\hline 13 & Ketepatan problem posing pada kegiatan inti & Baik \\
\hline 14 & $\begin{array}{l}\text { Ketepatan penarikan kesimpulan, refleksi, penilaian, dan umpan } \\
\text { balik pada kegiatan penutup }\end{array}$ & Sangat Baik \\
\hline 15 & $\begin{array}{l}\text { Kesesuaian dengan langkah-langkah pembelajaran pada } \\
\text { pendekatan problem posing }\end{array}$ & Baik \\
\hline 16 & $\begin{array}{l}\text { Memberikan kesempatan kepada pebelajar untuk berpikir secara } \\
\text { kritis dan sistematis }\end{array}$ & Baik \\
\hline 17 & $\begin{array}{l}\text { Kesesuaian sumber belajar terhadap ketercapaian tujuan } \\
\text { pembelajaran }\end{array}$ & Baik \\
\hline 18 & umhor holaiar dongan n & Baik \\
\hline 19 & deng & Baik \\
\hline 20 & Kesesuaian pemilihan teknik penilaian dengan tujuan pembelajaran & Baik \\
\hline 21 & Kesesuaian butir instrumen dengan tujuan pembelajaran & Baik \\
\hline 22 & enilaian dengan tujuan pembelajaran & Baik \\
\hline 23 & & angat Baik \\
\hline 24 & Keberadaan instrumen, kunci jawaban soal, dan rubrik penilaian & Baik \\
\hline
\end{tabular}

Diadopsi dan diadaptasi dari Wijayanti (2017)

\section{Hasil Tahap Do}

Tahap ini bertujuan untuk mengujicoba efektifitas model pembelajaran yang telah dirancang. Dosen-dosen lain dari jurusan lain bertindak sebagai pengamat (observer) pembelajaran. Dosen atau mahasiswa bisa melakukan pengamatan dalam pembelajaran tersebut. Pada kegiatan ini dilakukan pre-test \& post-test dengan tujuan untuk melihat peningkatan hasil belajar mahasiswa pada matakuliah fisika teknik pokok bahasan menghitung impuls dan momentum pada kendaraan dengan pendekatan problem posing melalui kegiatan lesson study. Hasil pre-test \& post-test dianalisis menggunakan tes "t" untuk dua sampel kecil yang satu sama lain saling berhubungan dengan langkah sebagai berikut.

1. Merumuskan hipotesis

$\mathrm{H}_{0} \quad$ : Tidak terdapat perbedaan hasil belajar mahasiswa sebelum dan sesudah mempelajari materi menghitung impuls dan momentum pada kendaraan dengan pendekatan problem posing melalui kegiatan lesson study

$\mathrm{H}_{\mathrm{a}} \quad$ : Terdapat perbedaan hasil belajar mahasiswa sebelum dan sesudah mempelajari materi menghitung impuls dan momentum pada kendaraan dengan pendekatan problem posing melalui kegiatan lesson study

2. Membuat desain deskripsi data dalam bentuk tabel bantu perhitungan " $\mathrm{t}$ " tes untuk dua sampel kecil yang saling berhubungan.

Tabel 3. Desain Deskripsi Data Pengujian "t" tes hasil belajar mahasiswa sebelum dan sesudah mempelajari materi menghitung impuls dan momentum pada kendaraan dengan pendekatan problem posing melalui kegiatan lesson study

\begin{tabular}{ccccc}
\hline Nomor Resp. & \multicolumn{2}{c}{ Skor } & $\mathrm{D}=(\mathrm{X}-\mathrm{Y})$ & $D^{2}(X-Y)^{2}$ \\
\cline { 2 - 3 } & Post-test $(\mathrm{X})$ & Pre-test $(\mathrm{Y})$ & & \\
\hline 1 & 84 & 78 & 6 & 36 \\
2 & 88 & 82 & 6 & 36 \\
3 & 90 & 78 & 12 & 144 \\
4 & 90 & 78 & 12 & 144 \\
5 & 90 & 82 & 8 & 64 \\
6 & 92 & 76 & 16 & 256 \\
7 & 92 & 72 & 20 & 400 \\
8 & 94 & 72 & 22 & 484 \\
9 & 94 & 76 & 18 & 324 \\
\hline
\end{tabular}




\begin{tabular}{|c|c|c|c|c|}
\hline \multirow[t]{2}{*}{ Nomor Resp. } & \multicolumn{2}{|c|}{ Skor } & \multirow[t]{2}{*}{$\mathrm{D}=(\mathrm{X}-\mathrm{Y})$} & \multirow[t]{2}{*}{$D^{2}(X-Y)^{2}$} \\
\hline & Post-test (X) & Pre-test $(\mathrm{Y})$ & & \\
\hline 10 & 96 & 86 & 10 & 100 \\
\hline 11 & 96 & 86 & 10 & 100 \\
\hline 12 & 94 & 76 & 18 & 324 \\
\hline 13 & 94 & 72 & 22 & 484 \\
\hline 14 & 92 & 72 & 20 & 400 \\
\hline 15 & 92 & 76 & 16 & 256 \\
\hline 16 & 90 & 82 & 8 & 64 \\
\hline 17 & 90 & 78 & 12 & 144 \\
\hline 18 & 90 & 78 & 12 & 144 \\
\hline 19 & 88 & 82 & 6 & 36 \\
\hline 20 & 84 & 78 & 6 & 36 \\
\hline 21 & 84 & 78 & 6 & 36 \\
\hline 22 & 88 & 82 & 6 & 36 \\
\hline 23 & 90 & 78 & 12 & 144 \\
\hline 24 & 90 & 78 & 12 & 144 \\
\hline 25 & 90 & 82 & 8 & 64 \\
\hline 26 & 90 & 82 & 8 & 64 \\
\hline 27 & 90 & 78 & 12 & 144 \\
\hline 28 & 90 & 78 & 12 & 144 \\
\hline 29 & 88 & 82 & 6 & 36 \\
\hline 30 & 84 & 78 & 6 & 36 \\
\hline 31 & 84 & 78 & 6 & 36 \\
\hline 32 & 84 & 78 & 6 & 36 \\
\hline$\Sigma$ & 2872 & 2512 & 360 & 4896 \\
\hline $\bar{x}$ & 89,75 & 78,5 & & \\
\hline
\end{tabular}

Diadopsi dan diadaptasi dari Wijayanti (2017)

3. Menghitung tobservasi dengan langkah-langkah sebagai berikut:

a. Mencari Mean of difference $=\mathrm{M}_{\mathrm{D}}$ :

$M_{D}=\frac{\Sigma D}{N}=\frac{360}{32}=11,25$

b. Mencari Deviasi standar $\left(\mathrm{SD}_{\mathrm{D}}\right)$ :

$\mathrm{SD}=$

$$
\begin{aligned}
& =\sqrt{\frac{\Sigma D^{2}}{N}-\left(\frac{(\Sigma D)}{(n)}\right)^{2}}=S D_{D}=\sqrt{\frac{4896}{32}-\left(\frac{360}{32}\right)^{2}} \\
& =\sqrt{153-126,5625}=\sqrt{26,4375}=\mathbf{5 , 1 4}
\end{aligned}
$$

C. Mencari Standar error (standar kesesatan) dari mean of different $=\left(S E_{M D}\right)$ :

$S E_{M D}=\frac{S D_{D}}{\sqrt{N-1}}=\frac{5,14}{\sqrt{32-1}}=\frac{5,14}{5,57}=0,92$

d. Menghitung Hasil tobservasi dengan formula statistik:

$\mathrm{t}_{\mathrm{o}}=\frac{M_{D}}{S E_{M D}}=\frac{11,25}{0,92}=12,23$

e. Interpretasi dan kesimpulan:

Dari hasil perhitungan $t_{0}=12,23$ dan bila dikonsultasikan dengan nilai tabel "t" pada taraf signifikansi $5 \%$ dan $\mathrm{df}=\mathrm{N}-1=32-1=31$ pada taraf signifikansi $5 \%$ tabel $=1,69$. Hal ini menunjukkan tobservasi $=12,23>1,69=$ tabel. Maka dapat diinterpretasikan, menerima hipotesis alternatif $\left(\mathrm{H}_{\mathrm{a}}\right)$ dan menolak hipotesis nol $\left(\mathrm{H}_{0}\right)$ yang berarti bahwa terdapat perbedaan hasil belajar mahasiswa sebelum dan sesudah mempelajari materi menghitung impuls dan momentum pada kendaraan dengan pendekatan problem posing melalui kegiatan lesson study, dan perbedaan tersebut cukup berarti. Sehingga dapat disimpulkan bahwa penerapan pendekatan problem posing 
melalui kegiatan lesson study, efektif. Peningkatan hasil belajar dapat dilihat dari perbandingan skor post-test dan pre-test. Pada Tabel 3, skor post-test $=89,75$ lebih tingi dari skor pre-test $=78,5$, sehingga dapat disimpulkan bahwa terjadi peningkatan hasil belajar fisika teknik dengan pendekatan problem posing melalui kegiatan lesson study.

\section{Hasil Tahap See}

Rangkuman hasil observasi pembelajaran dengan lesson study oleh observer disajikan pada Tabel 4 berikut.

Tabel 4. Rangkuman Hasil Observasi Pembelajaran dengan Lesson Study

\begin{tabular}{|c|c|c|c|}
\hline \multirow[t]{2}{*}{ Pertanyaan } & \multicolumn{3}{|c|}{ Rangkuman Jawaban } \\
\hline & Observer 1 & Observer 2 & Observer 3 \\
\hline $\begin{array}{l}\text { Apakah semua } \\
\text { mahasiswa belajar }\end{array}$ & $\begin{array}{l}\text { Mahasiswa } \\
\text { mengikuti } \\
\text { pembelajaran } \\
\text { dengan cukup } \\
\text { antusias, persiapan } \\
\text { dosen baik sehingga } \\
\text { mahasiswa tertib } \\
\text { mengikuti } \\
\text { pembelajaran. }\end{array}$ & $\begin{array}{l}\text { Mahasiswa } \\
\text { mengikuti tahap } \\
\text { awal perkuliahan } \\
\text { dengan baik \& } \\
\text { kondusif, persiapan } \\
\text { dilakukan dengan } \\
\text { baik serta terdapat } \\
\text { pre-test yang } \\
\text { disediakan oleh } \\
\text { dosen model. }\end{array}$ & $\begin{array}{l}\text { Ya, seluruh } \\
\text { mahasiswa mampu } \\
\text { mengerjakan pre- } \\
\text { test dengan baik, } \\
\text { selain itu, } \\
\text { mahasiswa juga } \\
\text { dapat menjawab } \\
\text { pertanyaan- } \\
\text { pertanyaan } \\
\text { pembuka dari } \\
\text { dosen. }\end{array}$ \\
\hline $\begin{array}{l}\text { Mahasiswa yang } \\
\text { tidak dapat } \\
\text { mengikuti } \\
\text { pembelajaran }\end{array}$ & $\begin{array}{l}\text { Mahasiswa paling } \\
\text { kanan baris kedua } \\
\text { seperti tidak konsen } \\
\text { pembelajaran, hal ini } \\
\text { ditunjukkan } \\
\text { fokusnya terbagi } \\
\text { dengan "gadget". }\end{array}$ & $\begin{array}{l}\text { Terdapat } 1 \\
\text { mahasiswa yang } \\
\text { tidak bisa mengikuti } \\
\text { perkuliahan karena } \\
\text { izin/sakit atas nama } \\
\text { Tria Ananta dan } \\
\text { terdapat seorang } \\
\text { mahasiswa yang } \\
\text { terlihat kesulitan } \\
\text { mengerjakan pre- } \\
\text { test. }\end{array}$ & $\begin{array}{l}\text { Seluruh mahasiswa } \\
\text { yang hadir dapat } \\
\text { mengikuti kegiatan } \\
\text { pembelajaran. }\end{array}$ \\
\hline $\begin{array}{l}\text { Mengapa } \\
\text { mahasiswa tidak } \\
\text { dapat belajar } \\
\text { dengan baik }\end{array}$ & $\begin{array}{l}\text { Dimungkinkan } \\
\text { mahasiswa tersebut } \\
\text { kurang menguasai } \\
\text { materi. }\end{array}$ & $\begin{array}{l}\text { Mahasiswa tersebut } \\
\text { dimungkinkan } \\
\text { kurang menguasai } \\
\text { materi/soal pre-test } \\
\text { yang diberikan oleh } \\
\text { dosen model. }\end{array}$ & - \\
\hline $\begin{array}{l}\text { Usaha dosen dalam } \\
\text { mendorong } \\
\text { mahasiswa belajar }\end{array}$ & $\begin{array}{l}\text { Dosen memberikan } \\
\text { review materi dan } \\
\text { meminta feed-back } \\
\text { ke mahasiswa untuk } \\
\text { mengetahui } \\
\text { pemahaman } \\
\text { mahasiswa. }\end{array}$ & $\begin{array}{l}\text { Dosen model } \\
\text { memberikan review } \\
\text { materi yang menjadi } \\
\text { kendala bagi } \\
\text { mahasiswa. }\end{array}$ & $\begin{array}{l}\text { Dosen memberi } \\
\text { kesempatan kepada } \\
\text { mahasiswa untuk } \\
\text { membentuk soal } \\
\text { dari kondisi yang } \\
\text { diberikan, } \\
\text { mendiskusikan dan } \\
\text { mempresentasikan } \\
\text { hasil diskusinya di } \\
\text { depan kelas. }\end{array}$ \\
\hline $\begin{array}{l}\text { Pelajaran berharga } \\
\text { yang dapat dipetik } \\
\text { dalam pembelajaran }\end{array}$ & $\begin{array}{l}\text { Mata kuliah fisika } \\
\text { teknik sesuai jika } \\
\text { dilaksanakan } \\
\text { dengan model } \\
\text { problem posing. }\end{array}$ & $\begin{array}{l}\text { Mata kuliah fisika } \\
\text { teknik merupakan } \\
\text { mata kuliah yang } \\
\text { dapat diterapkan } \\
\text { dengan metode }\end{array}$ & $\begin{array}{l}\text { Mengajak } \\
\text { mahasiswa untuk } \\
\text { berperan aktif dalam } \\
\text { jalannya } \\
\text { pembelajaran tidak }\end{array}$ \\
\hline
\end{tabular}




\begin{tabular}{|c|c|c|c|}
\hline \multirow[t]{2}{*}{ Pertanyaan } & \multicolumn{3}{|c|}{ Rangkuman Jawaban } \\
\hline & Observer 1 & Observer 2 & Observer 3 \\
\hline & & $\begin{array}{l}\text { problem posing, } \\
\text { sehingga sesuai } \\
\text { dengan } \\
\text { tujuan/capaian } \\
\text { lulusan yang } \\
\text { diharapkan. }\end{array}$ & $\begin{array}{l}\text { hanya membuat } \\
\text { pembelajaran } \\
\text { menjadi lebih baik, } \\
\text { tetapi mahasiswa } \\
\text { pun tampak merasa } \\
\text { puas dengan proses } \\
\text { belajarnya, dan } \\
\text { setiap kegiatan } \\
\text { harus diapresiasi. }\end{array}$ \\
\hline
\end{tabular}

\section{Pembahasan}

Berdasarkan data hasil penelitian yang tersaji di atas menunjukkan bahwa pembelajaran fisika teknik yang dirancang menggunakan pendekatan problem posing melalui kegiatan lesson study dapat meningkatkan hasil belajar mahasiswa. Hasil penelitian ini selaras dengan pendapat beberapa peneliti yang meneliti efektivitas problem posing pada pembelajaran, seperti 1) Rasmawan [13] menyimpulkan bahwa terdapat perbedaan yang signifikan antara kemampuan awal mahasiswa sebelum pembelajaran model problem posing dengan kemampuan akhir mahasiswa setelah pembelajaran model problem posing; dan 2) Gusnardi [14] menyimpulkan bahwa hasil belajar mahasiswa dalam mata kuliah perpajakan pada pokok bahasan PPh pasal 21 meningkat dengan menerapkan metode pembelajaran problem posing.

Keefektifan pendekatan problem posing dalam meningkatkan hasil belajar mahasiswa melibatkan unsur-unsur penting yang menjadi ciri khas strategi problem posing yaitu unsur matematika, struktur pembelajaran, dan respon pebelajar [2]. Unsur yang utama dalam strategi ini adalah perhitungan matematika. Pokok bahasan menghitung impuls dan momentum pada kendaraan di dalam ilmu fisika teknik dapat dipastikan melibatkan perhitungan matematika. Selaras dengan pendapat observer 1 yang mengatakan bahwa strategi problem posing paling sesuai untuk diterapkan dalam pembelajaran fisika teknik.

Unsur yang ke dua adalah struktur pembelajaran yang merupakan keunikan strategi problem posing, karena dalam pelaksanaannya, pembelajaran ini merupakan peralihan dari pembelajaran berpusat pada pengajar (teacher centered instruction) [15] kepada pembelajaran berpusat pada pebelajar (student centered instruction) [16]. Penyampaian materi oleh dosen di awal pelajaran merupakan pembelajaran berpusat pada pengajar, sedangkan selanjutnya problem posing oleh pebelajar dan penyelesaian soal oleh pebelajar yang lain merupakan pembelajaran berpusat pada pebelajar [2].

Unsur yang ke tiga dalam strategi ini adalah respon pebelajar. Dari kondisi yang diberikan oleh pengajar, diharapkan pebelajar memberi respon berupa soal. Dalam pembelajaran pokok bahasan menghitung impuls dan momentum pada kendaraan melibatkan hitungan atau operasi matematika, dimana pengajar meminta pebelajar untuk mengerjakan soal-soal yang mana menurut Moses et al [17] menyatakan bahwa situasi seperti ini menimbulkan rasa cemas yang besar pada diri pebelajar. Moses [18] juga mengatakan problem posing dapat menurunkan kecemasan matematis (mathematical anxiety) karena dalam penerapan strategi problem posing rasa cemas tidak terjadi sebab yang membuat soal adalah rekannya sendiri, dan bila soal tersebut sulit untuk dipecahkan maka pembuat soal yaitu rekannya akan menjelaskannya.

Keefektifan pendekatan problem posing dalam meningkatkan hasil belajar mahasiswa juga tak lepas dari kelebihan problem posing sebagai pendekatan pembelajaran yang melibatkan hitungan atau operasi matematika. Seperti yang diungkapkan Patahuddin (dalam Siswono, [19]) problem posing mempunyai beberapa kelebihan, antara lain: 1) memberi kesempatan kepada siswa untuk mencapai pemahaman yang lebih luas dan menganalisis secara lebih mendalam tentang suatu topik, 2) memotivasi siswa untuk belajar lebih lanjut, 3) memberi kesempatan kepada siswa untuk mengembangkan sikap kreatif, bertanggung jawab, dan berdiri sendiri; dan 4) pengetahuan akan lebih lama diingat siswa karena diperoleh dari hasil belajar atau hasil eksperimen yang berhubungan dengan minat mereka dan lebih terasa berguna untuk kehidupan mereka.

Sementara lesson study berperan sebagai "suplemen" untuk meningkatkan kualitas penerapan pendekatan problem posing perkuliahan fisika teknik. Menurut Lewis (2002), salah satu cara yang paling jelas untuk ditempuh dalam rangka berupaya meningkatkan pembelajaran adalah melakukan 
kolaborasi dengan dosen lain untuk merancang, mengamati dan melakukan refleksi terhadap pembelajaran yang dilakukan. Lesson study bukanlah metode atau model pembelajaran untuk mahasiswa, melainkan sebuah cara atau sistem untuk mengembangkan kemampuan dosen secara kolaboratif guna memperbaiki kualitas pembelajaran/pendidikan [20].

Dampak lesson study terhadap peningkatan hasil belajar mahasiswa tidak langsung. Peningkatan hasil belajar mahasiswa disebabkan penerapan pendekatan problem posing yang mana pada tahap plan, dosen-dosen dari jurusan lain di FT UM memberikan masukan kepada dosen model atas skenario pembelajaran/lesson plan yang berkaitan dengan 1) identitas mata kuliah, 2) rumusan indikator dan tujuan pembelajaran, 3) materi pembelajaran, 4) pemilihan pendekatan dan model pembelajaran, 5) kegiatan pembelajaran, 6) pemilihan sumber belajar, dan 7) penilaian belajar.

Pada tahap do di penelitian ini, beberapa observer mengatakan bahwa dosen model mempersiapkan pembelajaran dengan baik. Maka dapat disimpulkan bahwa pelaksanaan pembelajaran berbanding lurus dengan perencanaan pembelajaran. Jika perencanaan pembelajaran baik, maka dapat dipastikan pembelajaran menjadi efektif dan menarik. Sehingga tujuan utama penelitian ini yaitu terjadinya peningkatan hasil belajar mahasiswa pada matakuliah fisika teknik pokok bahasan menghitung impuls dan momentum pada kendaraan tercapai.

Keefektifan pelaksanaan lesson study dalam penelitian ini didukung berbagai data penelitian, seperti 1) Purwanto [21] yang menyimpulkan bahwa terbentuk kolaborasi antar-dosen dalam rangka perbaikan kualitas pembelajaran, 2) Misnar [22] yang menyimpulkan bahwa hasil pelaksanaan pembelajaran melalui model lesson study telah menunjukkan peningkatan kemampuan mahasiswa dalam speaking, 3) Supriyanto [23] mengatakan bahwa dengan lesson study dapat meningkatkan hasil belajar mahasiswa matakuliah teknik perkerasan jalan, 4) Hasanuddin [24] menarik kesimpulan bahwa melalui lesson study dapat meningkatkan keterampilan metakognitif siswa, dan 5) TMS Haratua [11] menyimpulkan bahwa implementasi lesson study dapat meningkatkan kualitas hasil perkuliahan.

Secara keseluruhan, penerapan lesson study menunjukkan peningkatan dalam konsistensi proses pembelajaran dan peningkatan keterampilan kerja tim. Itu bisa dilihat dari kelas yang tidak membosankan, karena sebagian besar siswa bersemangat belajar. Selalu ada manfaat bagi dosen untuk dapat berkolaborasi dengan teman sebaya dalam upaya meningkatkan pembelajaran mereka. Meskipun penelitian ini menunjukkan hasil yang baik, tidak mudah untuk mengubah perilaku belajar. Oleh karena itu, penerapan pendekatan ini akan terus berlangsung meski tidak selalu sama, setidaknya pola perilaku yang telah dikembangkan dapat dipertahankan.

Dari data penelitian diatas, dapat disimpulkan bahwa apapun pendekatan pembelajaran yang diterapkan melalui lesson study dapat meningkatkan kualitas pembelajaran. Hal ini didukung dengan pendapat Susilo [20] yang menjelaskan bahwa melalui lesson study dosen akan 1) lebih peduli akan hak mahasiswa untuk belajar dengan sebaik-baiknya, 2) berpikir mengenai bagaimana melaksanakan pembelajaran dengan sebaik-baiknya, 3) lebih serius membuat rencana pelaksanaan pembelajaran (RPP), karena hasil pemikiran salah seorang dosen akan diberi masukan oleh teman-teman dosen lainnya untuk memperbaiki/meningkatkan kualitas RPP-nya; 4) secara bersama-sama memilih dan menerapkan berbagai strategi atau materi pembelajaran yang seuai dengan situasi, kondisi, atau permasalahan pembelajaran yang dihadapi dosen; 5) membantu mahasiswa mencapai tujuan pembelajaran, 6) membantu mahasiswa belajar mengembangkan kebiasaan berpikir ilmiah, 7) melakukan perbaikan dengan dasar data, 8) memperhatikan motivasi dan iklim sosial, 9) memperoleh masukan yang langsung dapat diterima, 10) memberikan lingkungan belajar yang koheren dan konsisten, 11) mengadopsi pembelajaran sejenis di kelasnya sendiri, dan 12) mengembangkan keprofesionalannya.

\section{SIMPULAN DAN SARAN}

Berdasarkan hasil dan pembahasan, disimpulkan poin-poin sebagai berikut: 1) dari hasil perhitungan " $\mathrm{t}$ " tes menunjukkan tobservasi $=12,23>1,69=$ ttabel, yang berarti bahwa terdapat perbedaan hasil belajar mahasiswa sebelum dan sesudah mempelajari materi menghitung impuls dan momentum pada kendaraan dengan pendekatan problem posing melalui kegiatan lesson study, dan perbedaan tersebut cukup berarti. 2) Penerapan pendekatan problem posing melalui kegiatan lesson study, efektif dalam upaya meningkatkan hasil belajar fisika teknik pokok bahasan menghitung impuls dan momentum pada kendaraan, dibuktikan skor post-test $=89,75$ lebih tingi dari skor pre-test $=78,5$. 3) Keefektifan pendekatan problem posing dalam meningkatkan hasil belajar mahasiswa melibatkan unsur-unsur penting yang menjadi ciri khas strategi problem posing yaitu unsur matematika, struktur pembelajaran, dan respon pebelajar. 4) Lesson study berperan sebagai "suplemen" untuk 
meningkatkan kualitas penerapan pendekatan problem posing perkuliahan fisika teknik sehingga dampak lesson study terhadap peningkatan hasil belajar mahasiswa tidak langsung. 5) Pelaksanaan pembelajaran berbanding lurus dengan perencanaan pembelajaran, jika perencanaan pembelajaran baik, maka dapat dipastikan pembelajaran menjadi efektif dan menarik, sehingga tujuan pembelajaran tercapai. 6) Apapun pendekatan pembelajaran yang diterapkan melalui lesson study dapat meningkatkan kualitas pembelajaran.

Berdasarkan temuan hasil penelitian ini, peneliti menyampaikan saran-saran sebagai berikut: perlu dilakukan penelitian lanjutan tentang penerapan pendekatan pembelajaran lainnya melalui lesson study terutama berkaitan dengan peningkatan kemampuan berpikir kritis, peningkatan aktifitas belajar mahasiswa, peningkatan motivasi mahasiswa, peningkatan kualitas kemandirian dan kerjasama mahasiswa, dan variabel lainnya.

\section{DAFTAR PUSTAKA}

[1] U. N. M. Jurusan Teknik Mesin, Kurikulum Program Studi S1 Pendidikan Teknik Otomotif ( S1 PTO ). Malang: Universitas Negeri Malang, 2015.

[2] S. M. Iskandar, Pendekatan Pembelajaran SAINS Berbasis Konstruktivistis (Edisi Revisi). Media Nusa Creative, 2015.

[3] S. Sutiarso, Pengaruh Pembelajaran dengan Pendekatan Problem Posing Terhadap Hasil Belajar Aritmatika Siswa SMPN 18 Malang. Malang: Program Pasca Sarjana UM, 1999.

[4] I. G. P. Suharta, "Pengkonstruksian Masalah oleh Siswa (Suatu Strategi Pembelajaran Matematika).," in Seminar Nasional Pengajaran Matematika di Sekolah Menengah, 2000.

[5] R. A. O. Najoan, Analis Problem Posing Siswa Sekolah Dasar Negeri III Kecamatan Tomohon, Kabupaten Minahasa pada Konsep Hitungan Bilangan Cacah. Malang: Universitas Negeri Malang, 1999.

[6] A. R. As'ari, "Problem Posing untuk Peningkatan Profesionalisme Guru Matematika," J. Mat., vol. V, no. 1 , p. $2000,2000$.

[7] A. Azhar, Media Pembelajaran. Jakarta: PT Raja Grafindo Persada, 2001.

[8] J. Stepanek, "Researchers in Every Classroom," Northwest Teach. Spring, vol. 4, no. 3, pp. 2 5, 2003, doi: 10.16309/j.cnki.issn.1007-1776.2003.03.004.

[9] R. Perry, C. Lewis, S. Friedkin, and E. Baker, "Teachers' Knowledge Development During Lesson Study: Impact of Toolkit-Supported Lesson Study on Teachers' Knowledge of Mathematics for Teaching," in AERA, 2009.

[10] A. L. White and C. S. Lim, "Lesson Study in Asia Pacific classrooms: local responses," ZDM Math. Educ., vol. 40, pp. 915-925, 2008.

[11] T. Haratua, E. Octavianty, and Hamdani, "Implementasi Lesson Study untuk Meningkatkan Kualitas Perkuliahan Fisika Inti," J. Pendidik. Mat. dan IPA, vol. 2, no. 1, pp. 40-49, 2011.

[12] Zuriah, Penelitian Tindakan dalam Bidang Pendidikan dan Sosial. Malang: Banyu Publishing, 2003.

[13] R. Rasmawan, "Penerapan Model Problem Posing Bersetting Cooperatif Tipe Think Pair Share Pada Topik Asam Basa Untuk Meningkatkan Penguasaan Konsep Mahasiswa," J. Pendidik. Mat. dan IPA, vol. 1, no. 1, pp. 55-65, 2010.

[14] Gusnardi, "Peningkatan Hasil Belajar Mata Kuliah Perpajakan Pokok Bahasan PPh Psl 21 dengan Pendekatan Problem Posing Mahasiswa Pendidikan Ekonomi Universitas Riau," Pekbis J., vol. 5, no. 3, pp. 212-219, 2013.

[15] R. E. Slavin, Educational Psychology Theory and Practice (Eighth Edition). Boston: Pearson, 2006.

[16] P. A. Redolfo, A Elements of Student Centred Learning. Loyola Schools Loyola Antenoe de Manila University: Office of Reseacrh and Publication, 2001.

[17] B. Moses, E. Bjork, and E. P. Goldenberg, "Beyond Problem Solving: Problem Posing," Probl. Posing Reflections Appl., pp. 178-188, 1993.

[18] B. Moses, E. Bjork, and E. P. Goldenberg, "Beyond Problem Solving: Problem Posing," Teach. Learn. Math. 1990s, pp. 82-91, 1990.

[19] T. Y. E. Siswono, Metode Pemberian Tugas Pengajuan Soal (Problem Posing) dalam Pembelajaran Matematika Pokok Bahasan Perbandingan di MTs Negeri Rungkut Surabaya. Surabaya: PPs Unesa Surabaya, 1999.

[20] H. Susilo, Lesson Study Sebagai Sarana Membangun Komunitas Belajar Profesional 
(Professional Learning Community/PLC) dalam Mengembangkan Keterampilan Hidup Abad 21 (dalam Kerangka Technological, Pedagogical and Content Knowledge (TPACK) dalam Bahan Pelatihan Peningk. 2018.

[21] A. Purwanto, "Upaya Meningkatkan Kemampuan Mahasiswa Mengeksplor Mata Kuliah Sistematik Tumbuhan Rendah Melalui Lesson Study.," in Profesionalisme Guru Dalam Perspektif Global, 2012.

[22] Misnar, "Meningkatkan Prestasi Belajar Mahasiswa Prodi Pendidikan Bahasa Inggris Pada Mata Kuliah Speaking V Melalui Lesson Study," J. Pendidik. Almuslim, vol. 1, no. 1, 2013.

[23] B. Supriyanto, "Penerapan Pembelajaran Lesson Study Berbasis Kreatif Dan Produktif Pada Matakuliah Teknik Perkerasan Jalan Guna Meningkatkan Hasil Belajar Mahasiswa Prodi S1 Pendidikan Teknik Bangunan," Teknol. dan Kejuru., vol. 36, no. Pebruari, pp. 29-40, 2013.

[24] H. Syarifah, S. Indriwati, and A. Corebima, "Pengaruh Strategi Pembelajaran Reading Questioning and Answering (Rqa) Dipadu Think Pair Share (Tps) Terhadap Keterampilan Metakognitif Siswa Laki-Laki Dan Perempuan Sman Di Kota Malang," J. Pendidik. - Teor. Penelitian, dan Pengemb., vol. 1, no. 5, pp. 801-805, 2016, doi: 10.17977/jp.v1i5.6259. 